\title{
Evaluation of Applications to an Alcohol and Substance Dependence Research, Treatment and Training Centre (AMATEM): Data from Adiyaman Province in 2017
}

\author{
Oğuzhan Bekir Eğilmez ${ }^{1}$ iD , Mehmet Hamdi Örüm² ${ }^{\text {iD , Mahmut Zabit Karaª }}$ (iD
}

${ }^{1}$ Adıyaman Üniversitesi Eğitim ve Araştırma Hastanesi, Psikiyatri, Adıyaman, Türkiye

${ }^{2}$ Kahta Devlet Hastanesi, Psikiyatri, Adıyaman, Türkiye

${ }^{3}$ Sağlık Bilimleri Üniversitesi Antalya Eğitim ve Araştırma Hastanesi, Çocuk ve Ergen Ruh Sağlığı ve Hastalıkları, Antalya, Türkiye

Oğuzhan Bekir EĞiLMEZ, Dr. Öğr. Üyesi Mehmet Hamdi ÖRÜM, Uz. Dr. Mahmut Zabit KARA, Dr. Öğr. Üyesi

İletişim: Mehmet Hamdi Örüm Kahta Devlet Hastanesi, Psikiyatri, Adıyaman, Türkiye

Tel: +904167255067

E-Posta: mhorum@hotmail.com

Gönderilme Tarihi : 20 Haziran 2019

Revizyon Tarihi : 280 cak 2020

Kabul Tarihi : : 29 Şubat 2020

\begin{abstract}
Objective: Substance use disorder (SUD) continues to be a problem for the whole world in the first quarter of the twenty-first century. The leading centres in the treatment of SUD in our country are the Alcohol-Drug Dependence Research, Treatment and
\end{abstract} Training Centres (AMATEM). In this study, we aimed to examine 2017 data of the AMATEM outpatients in our province.

Materials and Methods: The study was conducted as a retrospective study of AMATEM applications between January 1, 2017 and December 31, 2017. Information such as gender, age and substance use characteristics of the applications were obtained from the patient recording system.

Results: A total of 211 applications were reached. The rate of men was $95.7 \%$, the female rate was $4.3 \%$, and the mean age was $26.09 \pm 7.87$ years. The mean age was significantly higher in patients with alcohol use disorder than in the other diagnoses. $86.4 \%$ of the patients were in the $20-29$ age range. $80.1 \%$ of the patients were diagnosed with opiate use disorder (OUD). The repeated applications were significantly higher in OUD than in other applicants. The rate of prescribing of buprenorphine+naloxane in OUD was $73.4 \%$. Buprenorphine, buprenorphine+opiate and opiate positivity was higher than other parameters in urine toxicology screen. In OUD, substance positivity in urine was significantly higher in opiate than in non-opiate patients.

Conclusion: This study is important in terms of revealing that opiate use is a serious problem in our province. At the same time, as far as we know, it is the first study of AMATEM outpatient data in our province. Further studies are needed in this field.

Keywords: Substance use disorder, opiates, heroin, AMATEM, epidemiology

Bir Alkol ve Madde Bağımlıı̆ı̆ı Tedavi ve Eğitim Merkezi (AMATEM)'ne Yapılan Başvuruların Değerlendirilmesi: 2017 Yilı Adıyaman Ili Verileri

ÖZET

Giriş: Madde kullanım bozuklukları (MKB) yirmi birinci yüzylın ilk çeyreğinin sonlarına gelirken tüm dünyayı ilgilendiren bir sorun olmaya devam etmektedir. Ülkemizde MKB tedavisinde en önde gelen merkezler Alkol-Madde Bağımlılı̆ı Araştırma Tedavi ve Eğitim Merkezleri (AMATEM)'dir. Biz bu çalışmada ilimizdeki tek AMATEM polikliniğine ait 2017 ylı verilerini incelemeyi amaçladık.

Gereç ve Yöntem: Çalısma, 1 Ocak 2017-31 Aralık 2017 tarihleri arasındaki AMATEM başvurularının retrospektif olarak incelenmesi şeklinde gerçekleştirildi. Başvurulara ait cinsiyet, yaş ve madde kullanım özellikleri gibi bilgilere hasta kayıt sisteminden ulaşıldı.

Bulgular: Toplamda 211 başvuruya ulaşıldı. Başvuruların erkek oranı \%95.7, kadın oranı \%4.3, ortalama yaş $26.09 \pm 7.87$ yıldı. Alkol kullanım bozukluğu başvurularında ortalama yaş diğer tanılara göre anlamlı olarak yüksekti. Hastaların \%86.4'ü 20-29 yaş aralığındaydı. Başvuruların \%80.1'inin tanısı opiyat kullanım bozukluğu (OPKB)'ydı. Mükerrer başvurular OPKB'de diğer başvurulara göre anlamlı olarak yüksekti. OPKB'de buprenorfin+naloksan reçetelenme oranı \% $73.4^{\prime} y d$ d. İdrarda toksik taramada en fazla buprenorfin, buprenorfin+opiyat ve opiyat pozitifliği saptandı. OPKB'de idrarda toksik taramada madde pozitifliği opiyat dışı madde kullanımlarına göre anlamlı olarak yüksekti.

Sonuçlar: Bu çalışma, ilimizde opiyat kullanımının ciddi bir sorun olduğunu göstermesi bakımından önemlidir. Aynı zamanda, bildiğimiz kadarılyla ilimizde AMATEM polikliniği verilerini inceleyen ilk çalışmadır. Bu alanda daha fazla çalışmaya ihtiyaç duyulmaktadır.

Anahtar sözcükler: Madde kullanım bozukluğu, opiyat, eroin, AMATEM, epidemiyoloji 
Substance dependence is a chronic mental disorder characterized by compulsive substance seeking and relapses despite its negative effects. In general, there is a sequence of addiction: intermediate use, recreational use, regular use, dependence. Recent studies in this area mostly focus on relapses occurring in the case of compulsive use and withdrawal (1-5). Addiction causes people to have social, economic and personal problems. Persons are using an increasing amount of substance due to developing tolerance. This causes them to live more physically and mentally than others. Dependency affects the brain and therefore the behaviour (6-8). The person who starts to experience more problems with his/her environment is in a vicious circle. In addition to the genetic characteristics in the emergence of addiction, environmental characteristics play an important role in the maintenance of drug addiction (9-11). On the other hand, biological processes contribute to continuity. The characteristics that lead patients to addiction are the features that remove them from treatment (12-15).

Given that many different substances are addictive, treatment methods for substances may also differ (16). Treatment varies depending on the person's characteristics and the problems associated with drug use. In many patients, the simultaneous presence of mental, occupational, general medical and social problems makes addiction treatment difficult. Substance use treatment is a combination of behavioural therapy and drug treatment $(17,18)$. For the rapidly growing substance use disorder (SUD) in the world, states are undergoing various policy changes and have to make new plans (19). There are various applications in our country within the scope of combating substance addiction. The most prominent centres in the treatment of SUD in our country are Alcohol and Substance Dependence Research, Treatment and Training Centres (AMATEM). AMATEMs have been in service since the 1980s and the number of centres they serve has been increasing. It is possible to say that these centres, where outpatient or inpatient services can be provided, have made some significant progress in our country, although it is early to say that they are in a certain standard. These clinics serve in the areas of termination of substance dependence and re-functioning of individuals. Treatment strategies are determined according to the individual because of the change in the risk factors of SUD. Periodic follow-ups are applied in order to maintain the ongoing sobriety. The examination services in these centres are voluntary. As a result of the examination, the treatment plan is explained to the person and his/her relatives and the treatment process is started. If necessary, hospitalization is made. Various psychotropic drugs are used in the treatment of substance use. The combination of buprenorphine+naloxone (BN) is one of these treatments which can be started with a specific protocol and the treatment process is continued to be followed frequently $(20,21)$.

When the data of AMATEM in our country is examined, it is seen that the results vary according to the region and year. Asan et al. (22) conducted an AMATEM study with 302 patients in 2013 and found a male ratio of $93.7 \%$. In this study substance percentages were as follows: $14.6 \%$ alcohol, $53.3 \%$ opiate, $5.6 \%$ cannabis, $3.6 \%$ other substances (volatile, cocaine, etc.), and mixed $22.8 \%$. Gokcearslan et al. (23) performed a study with 2008-year data and found a male ratio of $93.1 \%$ and a female ratio of $6.9 \%$. Savasan et al. (24), based on the data of 2011-2012, found the mean age of the patients to be 45.42 (years) and the male percentage was $96.9 \%$. In this study, it was reported that $78 \%$ of the patients had alcohol use disorder (AUD), $6 \%$ of them had SUD and $16 \%$ had both AUD and SUD. Savaşan et al. (24) emphasized that individual or group psychotherapy programs to be organized within the first six months or one year may be beneficial for the prevention of relapse. Karaagac et al. (25) retrospectively examined the patients followed-up in an AMATEM unit in Kayseri province between 2007 and 2015 and found the male percentage to be $94.8 \%$ and the mean age was 33.6 years. According to this study, the mean age of alcohol users was higher than the mean age of the drug users and the most common reason for admission was AUD (37.2\%), and the second most common cause of admission was cannabis use disorder (CUD) (34.1\%). Bulut et al. (26) reported that the male ratio was $69.8 \%$, the mean age was 36.02 years, the AUD diagnosis rate was $46.8 \%$, opiate use disorder (OUD) diagnosis rate was $42.1 \%$, and CUD diagnosis rate was $7.1 \%$. When the statistical data were analysed, it is seen that there has been an increase in opiate use in recent years. According to the report of the General Directorate of Security in Turkey in 2017, 12.932 heroin incidents occurred (an increase of $58.1 \%$ compared to 2016) and in these events, 19.359 suspects were caught (an increase of $60.1 \%$ compared to 2016) and $17.752 \mathrm{~kg}$ of heroin were captured (compared to 2016, an increase of $214 \%$ was seized (27). Considering that the substance use characteristics change over time, new studies are thought to be needed. In this study, we aimed to retrospectively examine the patients who have applied to our hospital for a period of one year. 


\section{Material and Method}

\section{Study Design}

Our study was planned retrospectively. In our hospital, the patients who met the criteria for the diagnosis of SUD according to the Diagnostic and Statistical Manual of Mental Disorders, $5^{\text {th }}$ Edition (DSM-5) (28) and who were identified at least once in urine toxicology screening were investigated and included in the study. The diagnosis category was determined according to the verbal statement of which type of substance they frequently prefer, and according to the fact that their statements are compatible with the result of the toxicology screening of urine: OUD, CUD, AUD, stimulant use disorder (SUD), hallucinogen use disorder (HUD), inhalant use disorder (IUD). Two hundred forty-three patient records for 2017 were obtained. Thirtytwo applications were excluded from the study due to a lack of diagnosis. Two thousand and eleven applications were included in the study. In this study, the number of cases in the study was based on the number of applications in the AMATEM outpatient clinic. For this study, Ethics Committee Approval was obtained from the Ethics Committee of our university (Decision: 2019/3-5).

\section{Biochemical Analysis}

Biochemical analysis is carried out in the laboratory of our hospital through an "instant-view multi-drug of excessive urine test kit". In our laboratory biochemical analysis of amphetamine, barbiturate, benzodiazepine, cocaine, phencyclidine, methamphetamine, morphine, tetrahydrocannabinol and tricyclic antidepressants is performed by immune-chromatographic methods. In these analysis findings, the minimum limit for urine; it was accepted as $500 \mathrm{ng} / \mathrm{mL}$ for "Methamphetamine" (MAMP), $50 \mathrm{ng} / \mathrm{mL}$ for cannabis agent Tetrahydrocannabinol (THC), $200 \mathrm{ng} / \mathrm{mL}$ for "Benzodiazepines" (BZD), $200 \mathrm{ng} / \mathrm{mL}$ for "Barbiturates" (BAR), $300 \mathrm{ng} / \mathrm{mL}$ for "Methadone" (EDDP), $1000 \mathrm{ng} / \mathrm{mL}$ for "Amphetamine" (AMPH), $25 \mathrm{ng} / \mathrm{mL}$ for "Phencyclidine" (PCP), $300 \mathrm{ng} / \mathrm{mL}$ for "Morphine" (OPIAT), $500 \mathrm{ng} / \mathrm{mL}$ for "Ecstasy" (MDMA), $10 \mathrm{ng} / \mathrm{mL}$ for "Acetylmorphine" (6AM), 20 ng/mL for "Bonsai" (K2-1), 10 ng/mL for "Bonsai" (K2-2), $5 \mathrm{ng} / \mathrm{mL}$ for "Buprenorphine" (BUP), $1000 \mathrm{ng} / \mathrm{mL}$ for "Ethyl Glucuronide" (EtG), and 300 ng/mL for "Cocaine" (COC).

\section{Statistical Analysis}

Statistical analysis of Windows SPSS 22.0 program (Statistical Package for the Social Sciences Inc.) was used. Descriptive statistics and continuous variables were expressed as mean \pm standard deviation and categorical variables as frequencies and percentages. Chi-square test was used for categorical data analysis. $p<0.05$ was accepted as statistical significance.

\section{Results}

The number of applications evaluated was 211. Of these, 202 (95.7\%) were male and 9 (4.3\%) were female. The mean age of all patients was $26.09 \pm 7.87$ years. The mean age was $26.10 \pm 7.94$ years in males and $25.66 \pm 6.44$ years in females and there was no significant difference between genders $(p=0.870)$.

There were 169 (80.1\%) patients who met the diagnosis of OUD, 27 (12.8\%) patients who met the diagnosis of CUB, $12(5.7 \%)$ patients who met the diagnosis of AUD, and 3 (1.4\%) patients who met the diagnosis of SUD. The mean age of the OUD group was $24.46 \pm 4.14$ years, the mean age of the CUD group was $25.33 \pm 5.51$ years, the mean age of the AUD group was $51.25 \pm 10.21$ years and the mean age of the SUD group was $24.00 \pm 7.81$ years. There was a significant difference in age between the alcohol group and all other diagnoses $(p=0.000)$.

184 (87.2\%) of the applications were admitted to our polyclinic in the past. When we evaluated the OUD as an only group and the remaining applications as another group, it was found that the percentage of previous applicants was higher in the OUD group. While the number of previous applications was $92.3 \%(n=156)$ in the OUD group, this rate was $66.7 \%(n=28)$ in the other groups, and the difference between them was significant $(p=0.000)$. In addition, $73.4 \%(n=124)$ of the OUD applications were prescribed $\mathrm{BN}$ combination.

Toxicology screening data in urine were evaluated. All patients had a toxicology screening of urine (Table 1). In $80(37.9 \%)$ of the applications, no substance was found. There were 54 (25.6\%) opiate positivity, 38 (18.0\%) BUP positivity and $3(1.4 \%)$ ethyl glucuronide positivity in the urine analysis. In the nine (4.3\%) applications, multiple substances were reported as positive.

When the toxicology screening data of the OUD group were evaluated separately; it is determined that there were 38 (22.5\%) BUP positivity, 16 (\%9.5) BUP+opiate positivity, 54 (\%32.0) opiate positivity. The forty-six (\%27.2) applications did not show any positivity. 


\begin{tabular}{|l|c|}
\hline \multicolumn{2}{|l|}{ Table 1. Toxicology Screening Data in Urine } \\
\hline Parameters & $\mathrm{n}(\%)$ \\
\hline Not Detected & $80(37.9)$ \\
\hline MAMP & $2(0.9)$ \\
\hline THC & $5(2.4)$ \\
\hline BZD & $3(1.4)$ \\
\hline AMPH & $1(0.5)$ \\
\hline OPIAT & $54(25.6)$ \\
\hline BUP & $38(18.0)$ \\
\hline EtG & $3(1.4)$ \\
\hline BUP+OPIAT & $16(7.6)$ \\
\hline Multiple & $9(4.3)$ \\
\hline Total & $211(100.0)$ \\
\hline $\begin{array}{l}\text { Abbreviations: MAMP: Methamphetamine; THC: Tetrahydrocannabinol; BZD: } \\
\text { Benzodiazepines; AMPH: Amphetamine; OPIAT: Opiate, morphine, acetyl } \\
\text { morphine; BUP: Buprenorphine; EtG: Ethyl Glucuronide }\end{array}$ \\
\hline
\end{tabular}

When we evaluated the OUD as an only group and the remaining applications as another group, it was found that there was a significant difference between the OUD group (\%27.2) and the others (\%37.9) in terms of substance negativity $(p=0.000)$.

When we look at the age ranges, $13.8 \%$ of the applications were in the $15-19$ age range; $55.2 \%$ of the applications were in the $20-24$ age range, and $31.2 \%$ of the applications were in the $25-29$ age range.

\section{Discussion}

In this study, AMATEM applications for 2017 were evaluated. The percentage of men obtained was consistent with the information in the literature. Male dominance was between $93.1-96.9 \%$ in the AMATEM studies (22-26). The majority of these data belong to 10 years ago but the number of men is still high. When the international data are analysed, although rates may change, it is seen that the prevalence of substance use is higher in men in many parts of the world (29). In our study, the mean age of all applications was 26.01 years, the mean age of male applicants was 26.10 years, and female applicants was 25.66 years. The mean patient age was reported between 33.645.42 years in studies (24-26). These differences are thought to be related to the ratio of people diagnosed with AUD. In our study, the mean age of the AUD group was significantly higher than the other groups. Savasan et al. (24) reported the AUD diagnosis ratio as 78\%; Karaagac et al. (25) reported as 37.2\%; Bulut et al. (26) reported the AUD ratio as $46.8 \%$. In our study, this ratio was only $4 \%$. When the literature is examined, it is seen that there are similar data in many developed and developing countries
(30). On the other hand, there may be several reasons for the high rate of OUD.

According to one study, the ratio of patients who applied for the treatment of heroin use in Ankara AMATEM to all patients was $8.7 \%$ in 2004 and it was reported that this ratio increased to $38 \%$ in 2009 . In this study, $2 \%$ of the young people under the age of 18 who were hospitalized were using heroin in 2004 and this figure was found to be $47 \%$ in 2009 (31). These results show that the substance use characteristics of individuals change over time and are determined by external factors. Over the years, the difficulties or conveniences experienced in achieving the substance, the state policy, the changes in the drug production areas, the market shares of the substances, the powers dominating the substance market are some conditions affecting the substance orientation (32-34). As a result of these data, the high number of OUD applications significantly affects the mean age of the groups.

Other data related to opiate use is the use of BN. As it is seen, the highest rate of positivity in urine toxicology screening is BUP. As this result is an AMATEM polyclinic data, the situation can be met normally. Patients who apply to the outpatient clinic for treatment are treated according to the results of toxicology screening in the urine in a certain way. The reason why the percentage of past applicants was significantly higher in the OUD group compared to the other groups is probably BN. This drug, which is an important stage for the continuation of treatment, also facilitates the patient's compliance with the treatment. On the other hand, both opiates and BUP were positive in a significant number of applications. It should be noted that this may be directly or indirectly related to $\mathrm{BN}$ abuse. Some of the people who can provide this medicine by illegal means think that they benefit from the drug and then apply to AMATEM polyclinics for treatment. This probable abuse, paradoxically, also allows the dissemination of experience of treatment efficacy among dependent individuals. In any case, the use of BN has several disadvantages other than the positive aspects. Previous reports had stated that both the state and clinicians should be careful in this respect and develop new strategies (35-37).

In our study, the age of substance use was almost immediately after puberty. The results of our study show that the mean age of the SUD is at a very risky point. Situations that increase the risk of substance use should be revealed at the regional level and even at the individual level if necessary. It is especially important for a few years after 
high school and during high school. It is important to pay attention to overcome this risky period in the lightest way by means of various policies that are unique to these periods (38-40).

Despite the significant findings in our study, there are various limitations. The major limitation of this study is its retrospective design. Another limitation is the possible use of substances that cannot be determined in the urine toxicology screen. By increasing the diversity of scales, expanding sociodemographic data and elaborating the history of substance use it might be possible to better assess the results.

As a result, this study shows that SUD is felt intensively at the age when the lack of impulse control due to puberty, applications to AMATEM policlinics are largely related to opiates, and BN combination is frequently prescribed in patients with opiates, and patients with BN associated with repetitive applications to the polyclinics are intensified. Studies are needed to clarify the aetiology of SUD and related situations and to determine their prevalence.

\section{Conflict of Interest}

The authors have not declared any conflicts of interest.

\section{Financial Support}

The authors have not declared any financial support.

\section{References}

1. Hu Y, Salmeron BJ, Krasnova IN, Gu H, Lu H, Bonci A, et al. Compulsive drug use is associated with imbalance of orbitofrontal- and prelimbic-striatal circuits in punishment-resistant individuals. Proc Natl Acad Sci U S A 2019;116(18):9066-71.

2. Egilmez $\mathrm{OB}$, Örüm $M H$, Kara MZ. Adıyaman ili AMATEM verilerinin geriye dönük olarak incelenmesi: 2018 yılı verileri. Bağımlıık Dergisi - Journal of Dependence 2019;20(2):88-96.

3. Egilmez OB, Örüm MH, Dumlupınar E, Egeli A. Denetimli serbestlik uygulaması kapsamında yapılan başvuruların geriye dönük olarak değerlendirilmesi: 2018 yılı verileri. Bağımlılık Dergisi - Journal of Dependence 2019;20(2):80-7.

4. Örüm $M H$, Kara $M Z$, Kuştepe A, Kalenderoğlu A. Bilişsel hatalar ve dikkat-eksikliği hiperaktivite bozukluğu belirtilerinin madde kullanım özellikleri ile ilişkisi. Bağımlılık Dergisi-Journal of Dependence 2019;20(2):47-60.

5. Ozen ME, Kalenderoglu A, Orum MH, Egilmez OB. Topiramate add-on for treatment of migraine-type headache cures alcohol dependence: A case report. Journal of Mood Disorders (JMOOD) 2017;7(4):241-2.

6. Koob GF Antireward, compulsivity, and addiction: seminal contributions of Dr. Athina Markou to motivational dysregulation in addiction. Psychopharmacology (Berl) 2017;234:1315-32.

7. Koob GF. Addiction is a reward deficit and stress surfeit disorder. Front Psychiatry, 2013;4:72.
8. Liu JF, Li JX. Drug addiction: a curable mental disorder? Acta Pharmacol Sin, 2018;39(12):1823-9.

9. Orum $\mathrm{MH}$, Kustepe $\mathrm{A}$, Kara $\mathrm{MZ}$, Dumlupinar E, Egilmez OB, Ozen $\mathrm{ME}$, et al. Addiction profiles of patients with substance dependency living in Adiyaman province. Med Science 2018;7(2):369-72.

10. Orum MH, Kara MZ, Egilmez OB, Kalenderoğlu A. Complete blood count alterations due to the opioid use: what about the lymphocyterelated ratios, especially in monocyte to lymphocyte ratio and platelet to lymphocyte ratio?, J Immunoassay Immunochem 2018;14:1-12.

11. Orum $M H$, Kara MZ, Egilmez OB. Relationship between immune cells and alcohol dependents and controls: what about the lymphocyterelated ratios? J Immunoassay Immunochem, 2018;39(3):348-50.

12. Orum $M H$, Kara MZ, Egilmez OB, Ozen ME, Kalendeoğlu A. Evaluation of probation implementations of drug users in Adiyaman university training and research hospital: A one-year retrospective study. Med Science 2018;7(4):754-8.

13. Ozen ME, Orum MH, Kalenderoglu A, Atmaca M. Attention-deficit/ hyperactivity disorder in patients attending remedial treatment due to substance use disorder in Adiyaman University Training and Research Hospital. Psychiatry and Behavioral Sciences 2018;8(2):57-62.

14. Kustepe A, Kalenderoglu A, Celik M, Kaya-Bozkurt E, Orum MH, Uguz S. Evaluation of impulsivity and complex attention functions of subjects with substance use: Sample from Adiyaman province. Med Science 2019;8(1):67-71.

15. Özen $M E$, Örüm $M H$, Kalenderoğlu $A$. Hot shower therapy in cannabinoid hyperemesis syndrome: A case report. FNG \& Bilim Tıp Dergisi 2018;4(3):142-4.

16. Kmiec J, Suffoletto B. Implementations of a text-message intervention to increase linkage from the emergency department to outpatient treatment for substance use disorders. J Subst Abuse Treat 2019;100:39-44.

17. Wilcox CE, Abbott CC, Calhoun VD. Alterations in resting-state functional connectivity in substance use disorders and treatment implications. Prog Neuropsychopharmacol Biol Psychiatry 2019;91:79-93.

18. Arterberry BJ, Treloar Padovano H, Foster KT, Zucker RA, Hicks BM. Higher average potency across the United States is associated with progression to first cannabis use disorder symptom. Drug Alcohol Depend 2019;195:186-92.

19. Wood E, Samet JH, Volkow ND. Physician education in addiction medicine. JAMA 2013;310(16):1673-4.

20. Evans EA, Zhu Y, Yoo C, Huang D, Hser YI. Criminal justice outcomes over 5 years after randomization to buprenorphine-naloxone or methadone treatment for opioid use disorder. Addiction 2019. Doi: 10.1111/add.14620.

21. Turan R, Yargic I.The relationship between substance abuse treatment completion, sociodemographics, substance use characteristics, and criminal history. Substance Abuse 2012;33(2):92-8.

22. Asan Ö, Tıkır B, Okay IT, Göka E. Bir AMATEM birimine başvuran alkol ve madde kullanım bozukluğu olan hastaların sosyodemografik ve klinik özellikleri. Bağımlılık Dergisi 2015;16(1):1-8.

23. Gokcearslan E, Ozgur O, Akgun R. Social service need for the treatment of alcohol and substance addiction "AMATEM CASE". International J Acad Res 2011;3(2):258-64.

24. Savaşan A, Engin E, Ayakdası D. Bir amatem kliniğinden taburcu olan bağımlı hastaların yaşam tarzı değişiklikleri ve nüks durumları. Psikiyatri Hemşireliği Dergisi 2013;4(2):75-9.

25. Karaagac H, Esenkaya-Usta $Z$, Usta A, Gümüş-Yarmali $M$, Godekmerdan A. Retrospective analysis of sociodemographic characteristics of inpatients at Kayseri Research and Training Hospital AMATEM Clinic. Dusunen Adam The Journal of Psychiatry and Neurological Sciences 2017;30:251-7. 
26. Bulut M, Savaş HA, Cansel N, Selek S, Kap Ö, Yumru M, et al. Gaziantep Üniversitesi alkol ve madde kullanım bozuklukları birimine başvuran hastaların sosyodemografik özellikleri. Bağımlılık Dergisi 2006;7:65-70.

27. Türkiye Uyuşturucu Raporu, Türkiye Cumhuriyeti İçişleri Bakanlığı Emniyet Genel Müdürlüğü Narkotik Suçlarla Mücadele Daire Başkanlığı, Ankara, 2018.

28. American Psychiatric Association. (2013). Diagnostic and statistical manual of mental disorders (5th ed.). Washington, DC: Author.

29. McHugh RK, Votaw VR, Sugarman DE, Greenfield SF. Sex and gender differences in substance use disorders. Clin Psychol Rev 2018;66:12-23.

30. Cheng HG, Kaakarli H, Breslau J, Anthony JC. Assessing changes in alcohol use and alcohol use disorder prevalence in the United States: Evidence from national surveys from 2002 through 2014. JAMA Psychiatry 2018;75(2):211-213.

31. Dilbaz N. Opiat bağımlılığı. (içinde) Madde Bağımlılığı Tanı ve Tedavi Kılavuzu El Kitabı. Ankara: T.C. Sağlık Bakanlığı Sağlık Hizmetleri Genel Müdürlüğü Yayını, 2012. Erişim: http://www.hasta.saglik.gov. tr/files/madde_kitabi. pdf_1124638346.pdf, 03.05.2015.

32. Deligianni E, Corkery JM, Schifano F, Lione LA. An international survey on the awareness, use, preference, and health perception of novel psychoactive substances (NPS). Hum Psychopharmacol 2017. Doi: 10.1002/hup.2581.

33. Rychert M, Wilkins C, Parker K, Witten K. Are government-approved products containing new psychoactive substances perceived to be safer and more socially acceptable than alcohol, tobacco and illegal drugs? Findings from a survey of police arrestees in New Zealand. Drug Alcohol Rev 2018;37(3):406-13.

34. Wilkins C, Parker K, Prasad J, Jawalkar S. Do police arrestees substitute legal highs for other drugs. Int J Drug Policy 2016;31:74-9.

35. Lee JD, Nunes EV.Jr, Novo P, Bachrach K, Bailey GL, Bhatt S, et al. Comparative effectiveness of extended-release naltrexone versus buprenorphine-naloxone for opioid relapse prevention (X:BOT): a multicentre, open-label, randomised controlled trial. Lancet 2018;391(10118):309-18.

36. Smith KE, Bunting AM, Walker R, Hall MT, Grundmann O, Castillo $\mathrm{O}$. Non-prescribed buprenorphine use mediates the relationship between heroin use and kratom use among a sample of polysubstance users. J Psychoactive Drugs 2019;1-12.

37. Wang $X$, Jiang $H$, Zhao M, Li J, Gray F, Sheng L, et al. Treatment of opioid dependence with buprenorphine/naloxone sublingual tablets: A phase 3 randomized, double-blind, placebo-controlled trial. Asia Pac Psychiatry 2019;11(1):e12344.

38. Jackson PR. A transgenerational perspective on prevention and treatment of adolescent substance use disorders. J Child Adolesc Psychopharmacol 2019. Doi: 10.1089/cap.2018.0174.

39. Kotlaja MM, Carson JV. Cannabis prevalence and national drug policy in 27 countries: An analysis of adolescent substance use. Int J Offender Ther Comp Criminol 2019;63(7):1082-99.

40. Lee TK, Estrada $Y$, Soares MH, Sánchez Ahumada M, Correa Molina $\mathrm{M}$, Bahamon MM, et al. Efficacy of a family-based intervention on parent-adolescent discrepancies in positive parenting and substance use among hispanic youth. J Adolesc Health 2019;64(4):494-501. 